\title{
Assessment of the scientific-technological production in molecular biology in Brazil (1996-2007): the contribution of genomics programs
}

\author{
ROGÉRIO MENEGHINI ${ }^{1,2,3}$ and ESTÊVÃO C. GAMBA ${ }^{2}$ \\ ${ }^{1}$ SciELO/Fundação de Apoio à Universidade Federal de São Paulo/UNIFESP \\ Rua Dr. Diogo de Faria, 1087, $8^{\circ}$ andar, cj. 801, Vila Clementino, 04037-003 São Paulo, SP, Brasil \\ ${ }^{2}$ Departmento de Informática Médica, Universidade Federal de São Paulo/UNIFESP \\ Rua Botucatu, 862, 04023-901 São Paulo, SP, Brasil \\ ${ }^{3}$ Fundação de Apoio à Universidade Federal de São Paulo/FapUNIFESP \\ Rua Dr. Diogo de Faria, 1087, $8^{\circ}$ andar, cj. 801, Vila Clementino, 04037-003 São Paulo, SP, Brasil \\ Manuscript received on July 8, 2010; accepted for publication on December 1, 2010
}

\begin{abstract}
Several genome sequencing programs were launched in Brazil by the end of the nineties and the early 2000 s. The most important initiatives were supported by the ONSA program (http://watson.fapesp.br/onsa/Genoma3.htm) and aimed at gaining domain in genomic technology and bringing molecular biology to the state of art. Two main sets of data were collected in the 1996-2007 period to evaluate the results of these genome programs: the scientific production (Scopus and Web of Science databases) and the register of patents (US Patent and Trademark Office), both related to the progress of molecular biology along this period. In regard to the former, Brazil took a great leap in comparison to 17 other developed and developing countries, being only surpassed by China. As to the register of patents in the area of molecular biology, Brazil's performance lags far behind most of the countries focused in the present study, confirming the Brazilian long-standing tendency of poor achievements in technological innovations when compared with scientific production. Possible solutions to surpass this inequality are discussed.
\end{abstract}

Key words: science assessment, genomics, scientometrics, molecular biology.

\section{INTRODUCTION}

Molecular biology of the gene is an area of contemporary science that permeates several other areas of life sciences. Its concepts and methods have been, for historical reasons, slowly absorbed by the Brazilian Scientific community. For example, in the period of 1965-1975 the ISI-Thomson Reuters database registered 24 articles published in Brazil in this area, involving approximately ten groups (search for key words expression described below). The authors belonged mainly to the areas of cytology and biochemistry, and the tendency was for a more descriptive study. In the same period, the United States published 6439 articles and a great number of

Correspondence to: Rogério Meneghini

E-mail: rogerio.meneghini@scielo.org them came from laboratories with competent groups in genetics, microbiology, virology and enzymology, which were the truly propelling areas of studies in molecular biology of the gene (Judson 1979). The lack of research groups in Brazil with proficiency in these areas was certainly a decisive factor for the slow progress of molecular biology in the following decades.

Taking these circumstances into consideration, this work aims at describing the evolution of scientific-technological production in molecular biology in Brazil and comparing it to international results, focusing the period of 1996-2007. The interpretation of the results related to such evolution was performed by investigating the impact of the implementation of genomics national programs, highlighting the production in the 
state of São Paulo, in view that it was the first one to launch these programs through the ONSA-FAPESP initiative (http://watson.fapesp.br/onsa/Genoma3.htm). In defense of the implementation of the ONSA genomics programs, there was the proposal of rescuing molecular biology (Perez 2002), maybe more important than genome sequencings themselves. The success of the latter is evident through the publications that they originated. What is less clear is how much such effort meant in terms of a molecular biology advance in Brazil. The recovery of information related to the national scientific production shows that the molecular biology area has achieved a very meaningful growth in Brazil. The fact that countries that had not launched genomics programs did not reach such leaps in molecular biology publications reinforces the assumption that Brazilian genomic programs (Simpson et al. 2000, Silva et al. 2002, Brazilian Genome Project Consortium et al. 2003) were fundamental for this progress. However, no technological spin off developments occurred paralleling the scientific progress and, therefore, the great impulse in molecular biology had no impact in terms of technological innovations.

\section{METHODOLOGY}

In order to retrieve scientific publications related to the molecular biology area, the SCOPUS database has been used. It was selected for its large coverage of high-impact journals in life sciences. The use of ISIThomson Reuters database was impaired due to the limited results displayed on-line. For example, it does not supply figures that outnumber 100,000 articles (case of the USA and China annual production). However, in one specific case, the SCOPUS and ISI-Thomson Reuters databases results were compared.

In order to recover such results, 1996 was adopted as the initial year, for that is the beginning of the Scopus database operational year and because the Brazilian genome programs were launched in the end of this decade. Data compilation occurred in August, 2008.

The expression "RNA OR DNA OR (MOLECULAR BIOLOGY) OR PCR" was employed for the search of texts that had at least one of these key-words. This search strategy was defined due to the fact that it is extremely comprehensive when compared to a great number of alternative expressions that have been tested. The results were distributed according to their authors' origin, which was sub-divided into four country groups: Latin-American countries (Argentina, Brazil, Chile and Mexico), developed countries (Germany, United States, United Kingdom, Japan, France and Canada); Asian and African emerging countries (South Africa, China, South Korea and India); and East European countries (Poland, Hungary and the Czech Republic). Finally, the results related to the scientific production in molecular biology in each of these countries were compared to the total scientific production in order to find clues for the progress of molecular biology research in each country.

In order to assess the scientific production impact on technological innovation, the registration of patents at the American United States Patent and Trademark Office (USPTO) was used. The covered period was also from 1996 to 2007.

\section{TOTAL SCIENTIFIC PRODUCTION GROWTH AND MOLECULAR BIOLOGY GROWTH IN BRAZIL, IN CONNECTION TO THE INTERNATIONAL SCIENTIFIC PRODUCTION (1996-2007)}

\section{BRAZIL IN THE CONTEXT OF LATIN-AMERICAN}

\section{COUNTRIES}

Brazil occupies the leading position in the Latin-American context, where the scientific production growth rate in the period from 1996 to 2007 is considered. According to Table I, the Brazilian scientific production in this period increased $236 \%$, followed by the production of Chile, Mexico and Argentina, which showed increases of $170 \%, 103 \%$ and $75 \%$, respectively.

When the scientific production growth rate in molecular biology is analyzed, Brazil also holds the first place in the rank, with an even more dramatic increase of $434 \%$ in the 1996-2007 period, followed by Chile, Argentina and Mexico, with increases of $228 \%, 202 \%$ and $160 \%$, respectively (Table II).

\section{BraZil in COMPARISON With DEVEloped COUNTRIES}

When the Brazilian rate of growth of the scientific production is compared to developed countries rates in the period of 1996-2007, it is observed that Brazil remains holding the first position in the rank (Table III). As already shown in Table I, Brazil had an increase of 
TABLE I

Growth of total scientific production in Brazil, Mexico, Argentina and Chile, on SCOPUS database (1996-2007).

\begin{tabular}{c|c|c|c|c|c|c|c|c}
\hline \multirow{2}{*}{ Year } & \multicolumn{2}{|c|}{ Brazil } & \multicolumn{2}{c|}{ Mexico } & \multicolumn{2}{c}{ Argentina } & \multicolumn{2}{c}{ Chile } \\
\cline { 2 - 10 } & Total & \% Growth & Total & \% Growth & Total & \% Growth & Total & \% Growth \\
\hline 1996 & 8,593 & - & 6,447 & - & 4,077 & - & 1,736 & - \\
\hline 1997 & 10,289 & 19.74 & 6,915 & 7.26 & 4,603 & 12.90 & 1,866 & 7.49 \\
\hline 1998 & 11,413 & 10.92 & 7,240 & 4.70 & 4,656 & 1.15 & 1,804 & -3.32 \\
\hline 1999 & 12.391 & 8.57 & 7,631 & 5.40 & 4,902 & 5.28 & 2,040 & 13.08 \\
\hline 2000 & 13,388 & 8.05 & 7,713 & 1.07 & 5,212 & 6.32 & 2,034 & -0.29 \\
\hline 2001 & 13,698 & 2.32 & 7,901 & 2.44 & 5,211 & -0.02 & 2,109 & 3.69 \\
\hline 2002 & 15,804 & 15.37 & 8,538 & 8.06 & 5,514 & 5.81 & 2,528 & 19.87 \\
\hline 2003 & 18,099 & 14.52 & 10,049 & 17.70 & 5,878 & 6.60 & 3,035 & 20.06 \\
\hline 2004 & 20,252 & 11.90 & 11,272 & 12.17 & 6,019 & 2.40 & 3,285 & 8.24 \\
\hline 2005 & 22,499 & 11.10 & 12,615 & 11.91 & 6,299 & 4.65 & 3,682 & 12.09 \\
\hline 2006 & 27,376 & 21.68 & 13,630 & 8.05 & 6,894 & 9.45 & 4,504 & 22.32 \\
\hline 2007 & 28,841 & 5.35 & 13,070 & -4.11 & 7,150 & 3.71 & 4,684 & 4.00 \\
\hline Total & $\mathbf{2 0 2 , 6 4 3}$ & & $\mathbf{1 1 3 , 0 2 1}$ & & $\mathbf{6 6 , 4 1 5}$ & & $\mathbf{3 3 , 3 0 7}$ & \\
\hline Growth 1996-2007 & $\mathbf{2 3 6 \%}$ & & $\mathbf{1 0 3 \%}$ & & $\mathbf{7 5 \%}$ & & $\mathbf{1 7 0 \%}$ \\
\hline
\end{tabular}

TABLE II

Growth of scientific production in molecular biology in Brazil, Mexico, Argentina and Chile, on SCOPUS database (1996-2007).

\begin{tabular}{|c|c|c|c|c|c|c|c|c|}
\hline \multirow[b]{2}{*}{ Year } & \multicolumn{2}{|c|}{ Brazil } & \multicolumn{2}{|c|}{ Mexico } & \multicolumn{2}{|c|}{ Argentina } & \multicolumn{2}{|c|}{ Chile } \\
\hline & $\begin{array}{l}\text { Molec. } \\
\text { Biology }\end{array}$ & $\begin{array}{c}\% \\
\text { Growth }\end{array}$ & $\begin{array}{l}\text { Molec. } \\
\text { Biology }\end{array}$ & $\begin{array}{c}\% \\
\text { Growth }\end{array}$ & $\begin{array}{l}\text { Molec. } \\
\text { Biology }\end{array}$ & $\begin{array}{c}\% \\
\text { Growth }\end{array}$ & $\begin{array}{l}\text { Molec. } \\
\text { Biology }\end{array}$ & $\begin{array}{c}\% \% \\
\text { Growth }\end{array}$ \\
\hline 1996 & 361 & - & 303 & - & 197 & - & 82 & - \\
\hline 1997 & 410 & 13.57 & 352 & 16.17 & 220 & 11.68 & 75 & -8.54 \\
\hline 1998 & 571 & 39.27 & 359 & 1.99 & 246 & 11.82 & 93 & 24.00 \\
\hline 1999 & 653 & 14.36 & 387 & 7.80 & 231 & -6.10 & 116 & 24.73 \\
\hline 2000 & 763 & 16.85 & 430 & 11.11 & 293 & 26.84 & 121 & 4.31 \\
\hline 2001 & 721 & -5.50 & 457 & 6.28 & 352 & 20.14 & 131 & 8.26 \\
\hline 2002 & 948 & 31.48 & 495 & 8.32 & 389 & 10.51 & 145 & 10.69 \\
\hline 2003 & 1,203 & 26.90 & 649 & 31.11 & 456 & 17.22 & 202 & 39.31 \\
\hline 2004 & 1,349 & 12.14 & 647 & -0.31 & 464 & 1.75 & 228 & 12.87 \\
\hline 2005 & 1,397 & 3.56 & 749 & 15.77 & 475 & 2.37 & 243 & 6.58 \\
\hline 2006 & 1,749 & 25.20 & 778 & 3.87 & 545 & 14.74 & 257 & 5.76 \\
\hline 2007 & 1,928 & 10.23 & 787 & 1.16 & 595 & 9.17 & 269 & 4.67 \\
\hline Total & 12,053 & & 6,393 & & 4,463 & & 1,962 & \\
\hline \multicolumn{2}{|c|}{ \% Growth 1996-2007 } & $434 \%$ & & $160 \%$ & & $202 \%$ & & $228 \%$ \\
\hline
\end{tabular}

$236 \%$, followed by Canada with 54\%, United Kingdom with $42 \%$, Germany with $38 \%$, France with 35\%, Japan with $16 \%$ and the United States with $12 \%$ (Table III).

In molecular biology, the Brazilian growth of $434 \%$ (Table II) is even more highlighted when compared to developed countries: Germany with $62 \%$, Canada with $57 \%$, United Kingdom with 40\%, Japan with $35 \%$, France with $27 \%$ and the United States with $20 \%$ (Table IV).
BRAZIL IN THE SCENERY OF RAPIDLY

DEVELOPING COUNTRIES

Regarding the rapidly emerging countries, the total growth of China's scientific publications is the highest in the world. According to the SCOPUS database, its increase in the 1996-2007 period was of 583\%, followed by South Korea, with 291\%, Brazil with 236\%, India with 115\%, and South Africa with 71\% (Table V). 

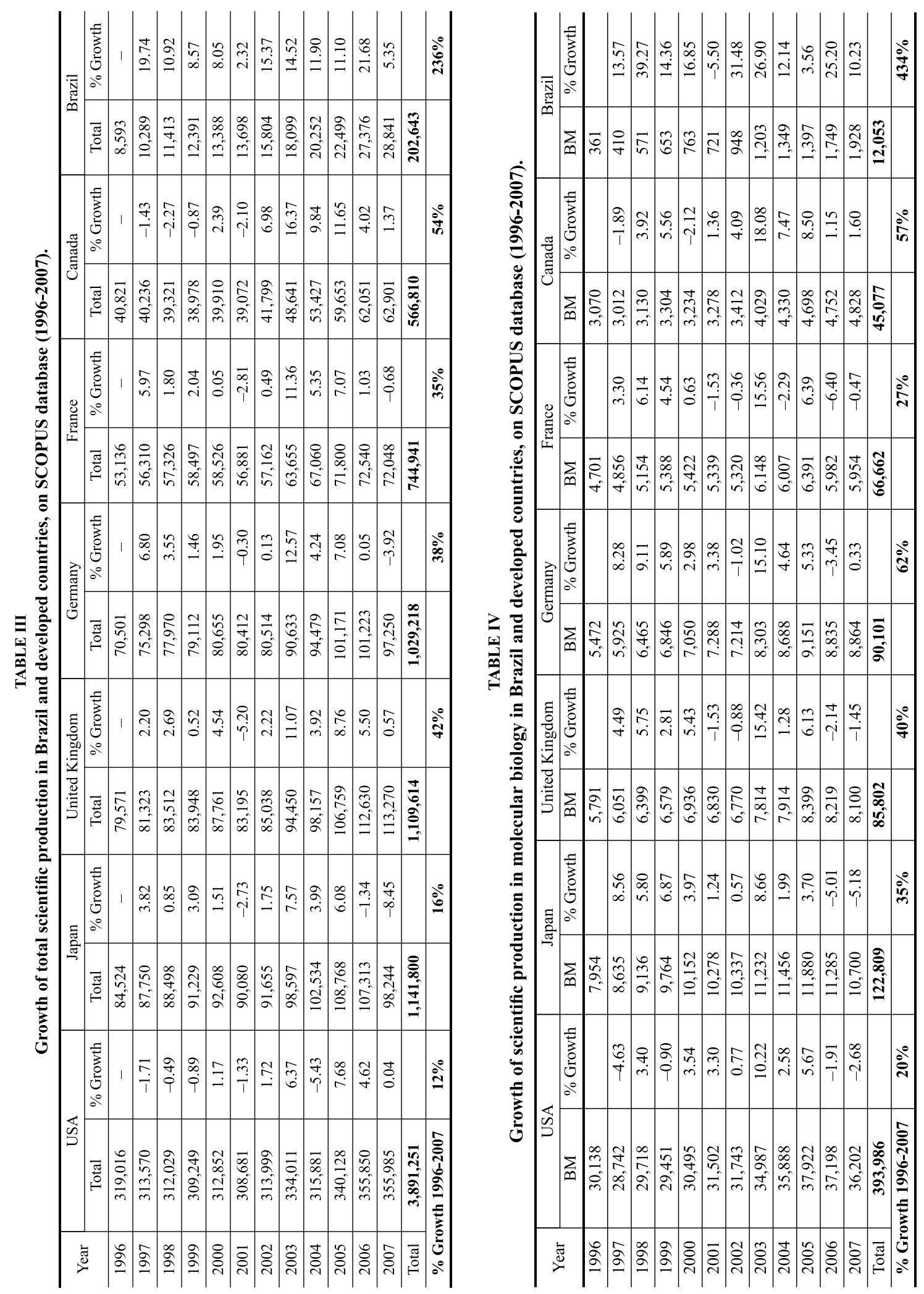
Brazil holds the first place in previous ranks of scientific production, but here it falls to third place. At any rate, Chinese, South Korean and Brazilian predominance in science growth all over the world is evident.

If we compare the Brazilian scientific production in molecular biology to the production of developing countries, we may observe that Brazil holds the second place in the rank with a total of $434 \%$, presenting lower results than China, which has reached an increase of $1243 \%$ (Table VI). South Korea is behind Brazil in this area, with $354 \%$, followed by India with $324 \%$ and South Africa with $175 \%$.

\section{Brazil and East EuRopean CoUntries}

When compared to East European countries, the Brazilian scientific production growth reached $236 \%$, more than the double increase presented by the Czech Republic, with $93 \%$. After it comes Poland with $74 \%$ and Hungary with 55\% (Table VII).

In molecular biology, the difference between Brazil and East European countries decreased, but its production growth remains more expressive than the growth presented by Poland, the Czech Republic and Hungary (Table VIII).

\section{TOTAL AND MOLECULAR BIOLOGY SCIENTIFIC PRODUCTION GROWTHS IN THE STATE OF SÃO PAULO (SCOPUS AND ISI DATABASES)}

São Paulo was the pioneering state in genome projects through the ONSA program of FAPESP. A network was organized for this purpose, which encompassed over one hundred scientists from more than forty institutions of the São Paulo State (Simpson et al. 2000; Silva et al. 2002, Brazilian Genome Project Consortium et al. 2003). With the aim of focusing the state of São Paulo production, it was chosen to compare publication data from Scopus and ISI-Thomson Reuters databases in this case. Here, besides the expression "RNA OR DNA OR (MOLECULAR BIOLOGY) OR PCR", the origin (SÃO PAULO or SP and BRASIL or BRAZIL) was also considered in the searches.

In order to view all the data obtained in SCOPUS and ISI databases, the results were presented in charts placed side by side. As it has already been mentioned above, the non-use of the ISI database for studies with countries was due to the fact that the standard database available at the Internet does not allow for definition of figures that outnumber 100,000 (e.g., the USA and China annual production).

The scientific production evolution in the state of São Paulo recovered from the SCOPUS database showed an increase of $257 \%$ in the 1996-2007 period (Table IX). In the ISI database, the increase was of $218 \%$ (Table X). The increase of $257 \%$ was a little higher than the Brazilian increase (236\%) in the same period (SCOPUS database, Table I).

In molecular biology, the scientific production in the state of São Paulo had expressive increases of $515 \%$ on the SCOPUS database (Table XI) and of $468 \%$ on the ISI database (Table XII). Therefore, the SCOPUS database reveals that, in this area, the São Paulo scientific production increase was 19\% higher than the Brazilian one (Table II).

Table XIII provides a summary chart of the total scientific production and in molecular biology, comparing Brazil, the state of São Paulo and 16 selected countries. China, as we have already seen, has had an impressive increase of $1,243 \%$ in molecular biology in the 1996-2007 period. In 1995, China defined the BioTechnology area as its priority number 1 in the National Plan for High Technology, among the 7 areas that had been selected as priorities (Zhangliang and Li-Jia 1997). Resources and efforts were higher than the ones from any other emerging country, and this fact may explain the great progress they reached in this area.

The Brazilian growth in molecular biology is also impressive (434\%), reaching the second place among the countries in the present study. The state of São Paulo was highlighted in Table XIII due to its pioneering genome sequencing programs that have certainly influenced the advance of molecular biology, being higher than the Brazilian average (515\%). It is difficult to find another explanation for the advances of molecular biology in Brazil and, more specifically, in the state of São Paulo.

It is interesting to mention that South Korea had a more modest growth in molecular biology in comparison to its total scientific production growth, with which it reaches the second place in the world. It is widely known that South Korea has presented an extraordinary 
TABLE V

Growth of scientific production of Brazil and Asian and African emerging countries, on SCOPUS database (1996-2007).

\begin{tabular}{|c|c|c|c|c|c|c|c|c|c|c|}
\hline \multirow{2}{*}{ Year } & \multicolumn{2}{|c|}{ China } & \multicolumn{2}{|c|}{ India } & \multicolumn{2}{|c|}{ South Korea } & \multicolumn{2}{|c|}{ Brazil } & \multicolumn{2}{|c|}{ South Africa } \\
\hline & Total & $\%$ Growth & Total & $\%$ Growth & Total & $\%$ Growth & Total & $\%$ Growth & Total & $\%$ Growth \\
\hline 1996 & 28,484 & - & 20,490 & - & 9,745 & - & 8,593 & - & 4,172 & - \\
\hline 1997 & 31,236 & 9.66 & 21,058 & 2.77 & 11,933 & 22.45 & 10,289 & 19.74 & 4,237 & 1.56 \\
\hline 1998 & 36,463 & 16.73 & 21,698 & 3.04 & 12,647 & 5.98 & 11,413 & 10.92 & 4,362 & 2.95 \\
\hline 1999 & 37,632 & 3.21 & 22,846 & 5.29 & 14,665 & 15.96 & 12,391 & 8.57 & 4,514 & 3.48 \\
\hline 2000 & 45,852 & 21.84 & 23,284 & 1.92 & 16,532 & 12.73 & 13,388 & 8.05 & 4,381 & -2.95 \\
\hline 2001 & 60,936 & 32.90 & 24,280 & 4.28 & 18,557 & 12.25 & 13,698 & 2.32 & 4,473 & 2.10 \\
\hline 2002 & 62,256 & 2.17 & 25,990 & 7.04 & 19,651 & 5.90 & 15,804 & 15.37 & 4,980 & 11.33 \\
\hline 2003 & 74,896 & 20.30 & 29,972 & 15.32 & 24,777 & 26.09 & 18,099 & 14.52 & 5,329 & 7.01 \\
\hline 2004 & 111,274 & 48.57 & 32,311 & 7.80 & 29,126 & 17.55 & 20,252 & 11.90 & 5,899 & 10.70 \\
\hline 2005 & 157,893 & 41.90 & 36,403 & 12.66 & 33,767 & 15.93 & 22,499 & 11.10 & 6,474 & 9.75 \\
\hline 2006 & 181,041 & 14.66 & 40,981 & 12.58 & 37,324 & 10.53 & 27,376 & 21.68 & 7,152 & 10.47 \\
\hline 2007 & 194,436 & 7.40 & 44,135 & 7.70 & 38,073 & 2.01 & 28,841 & 5.35 & 7,148 & -0.06 \\
\hline Total & $1,022,399$ & & 343,448 & & 266,797 & & 202,643 & & 63,121 & \\
\hline \multicolumn{2}{|c|}{ \% Growth 1996-2007 } & $583 \%$ & & $115 \%$ & & $291 \%$ & & $236 \%$ & & $71 \%$ \\
\hline
\end{tabular}

TABLE VI

Growth of scientific production in molecular biology of Brazil and Asian and African developing countries, on SCOPUS database (1996-2007).

\begin{tabular}{|c|c|c|c|c|c|c|c|c|c|c|}
\hline \multirow[b]{2}{*}{ Year } & \multicolumn{2}{|c|}{ China } & \multicolumn{2}{|c|}{ India } & \multicolumn{2}{|c|}{ South Korea } & \multicolumn{2}{|c|}{ Brazil } & \multicolumn{2}{|c|}{ South Africa } \\
\hline & $\begin{array}{l}\text { Molec. } \\
\text { Biology }\end{array}$ & $\begin{array}{c}\% \\
\text { Growth }\end{array}$ & $\begin{array}{l}\text { Molec. } \\
\text { Biology }\end{array}$ & $\begin{array}{c}\% \\
\text { Growth }\end{array}$ & $\begin{array}{l}\text { Molec. } \\
\text { Biology }\end{array}$ & $\begin{array}{c}\% \\
\text { Growth }\end{array}$ & $\begin{array}{l}\text { Molec. } \\
\text { Biology }\end{array}$ & $\begin{array}{c}\% \\
\text { Growth }\end{array}$ & $\begin{array}{l}\text { Molec. } \\
\text { Biology }\end{array}$ & $\begin{array}{c}\% \\
\text { Growth }\end{array}$ \\
\hline 1996 & 794 & - & 548 & - & 677 & - & 361 & - & 172 & - \\
\hline 1997 & 994 & 25.19 & 563 & 2.74 & 766 & 13.15 & 410 & 13.57 & 189 & 9.88 \\
\hline 1998 & 1,400 & 40.85 & 669 & 18.83 & 966 & 26.11 & 571 & 39.27 & 196 & 3.70 \\
\hline 2000 & 2,528 & 40.84 & 780 & 12.72 & 1,249 & 16.73 & 763 & 16.85 & 256 & 20.75 \\
\hline 2001 & 3,168 & 25.32 & 941 & 20.64 & 1,436 & 14.97 & 721 & -5.50 & 282 & 10.16 \\
\hline 2002 & 4,116 & 29.92 & 1,097 & 16.58 & 1,550 & 7.94 & 948 & 31.48 & 291 & 3.19 \\
\hline 2003 & 5,683 & 38.07 & 1,346 & 22.70 & 2,070 & 33.55 & 1,203 & 26.90 & 367 & 26.12 \\
\hline 2006 & 9,979 & 12.34 & 2,125 & 16.12 & 2,927 & 6.01 & 1,749 & 25.20 & 471 & 11.61 \\
\hline 2007 & 10,666 & 6.88 & 2,323 & 9.32 & 3,072 & 4.95 & 1,928 & 10.23 & 473 & 0.42 \\
\hline Total & 57,342 & & 14,442 & & 20,880 & & 12,053 & & 3,698 & \\
\hline \multicolumn{2}{|c|}{ \% Growth 1996-2007 } & $1243 \%$ & & $324 \%$ & & $354 \%$ & & $434 \%$ & & $175 \%$ \\
\hline
\end{tabular}

impulse in technological innovation, holding the fourth place in the world in deposits of patents in the US Patent Office, only behind the USA, Japan and Germany. However, as opposed to China and Brazil, there was not any special effort in the molecular biology and bio-technology areas, and the investments were primordially aimed to the engineering, physics and chemistry areas.
It should be observed that for all countries the growth of molecular biology production has been higher than their total production, except in the United Kingdom and France. The average production of molecular biology increased the double regarding the total production in the 1996-2007 period $(1.97+0.82$, Table XIII). This time period coincides with genomes se- 
TABLE VII

Growth of scientific production in Brazil and East European countries on SCOPUS database (1996-2007).

\begin{tabular}{c|c|c|c|c|c|c|c|c}
\hline \multirow{2}{*}{ Year } & \multicolumn{2}{|c|}{ Brazil } & \multicolumn{2}{c|}{ Poland } & \multicolumn{2}{c}{ Czech Republic } & \multicolumn{2}{c}{ Hungary } \\
\cline { 2 - 10 } & Total & \% Growth & Total & \% Growth & Total & \% Growth & Total & \% Growth \\
\hline 1996 & 8,593 & - & 11,300 & - & 4,866 & - & 4,222 & - \\
\hline 1997 & 10,289 & 19.74 & 11,329 & 0.26 & 5,196 & 6.78 & 4,730 & 12.03 \\
\hline 1998 & 11,413 & 10.92 & 11,588 & 2.29 & 5,259 & 1.21 & 5,096 & 7.74 \\
\hline 1999 & 12,391 & 8.57 & 12,324 & 6.35 & 5,640 & 7.24 & 4,794 & -5.93 \\
\hline 2000 & 13,388 & 8.05 & 13,062 & 5.99 & 5,792 & 2.70 & 5,138 & 7.18 \\
\hline 2001 & 13,698 & 2.32 & 13,784 & 5.53 & 6,204 & 7.11 & 4,808 & -6.42 \\
\hline 2002 & 15,804 & 15.37 & 15,037 & 9.09 & 6,474 & 4.35 & 5,049 & 5.01 \\
\hline 2003 & 18,099 & 14.52 & 17,748 & 18.03 & 7,662 & 18.35 & 5,635 & 11.61 \\
\hline 2004 & 20,252 & 11.90 & 19,416 & 9.40 & 8,235 & 7.48 & 5,937 & 5.36 \\
\hline 2005 & 22,499 & 11.10 & 21,059 & 8.46 & 8,738 & 6.11 & 6,651 & 12.03 \\
\hline 2006 & 27,376 & 21.68 & 22,258 & 5.69 & 9,812 & 12.29 & 6,761 & 1.65 \\
\hline 2007 & 28,841 & 5.35 & 19,689 & -11.54 & 9,402 & -4.18 & 6,557 & -3.02 \\
\hline Total & $\mathbf{2 0 2 , 6 4 3}$ & & $\mathbf{1 8 8 , 5 9 4}$ & & $\mathbf{8 3 , 2 8 0}$ & & $\mathbf{6 5 , 3 7 8}$ & $\mathbf{9 3 \%}$ \\
\hline \% Growth $\mathbf{1 9 9 6 - 2 0 0 7}$ & $\mathbf{2 3 6 \%}$ & & $\mathbf{7 4 \%}$ & & $\mathbf{5 5 \%}$ \\
\hline
\end{tabular}

TABLE VIII

Growth of scientific production in molecular biology - Brazil and East European countries; on SCOPUS database (1996-2007).

\begin{tabular}{|c|c|c|c|c|c|c|c|c|}
\hline \multirow{2}{*}{ Year } & \multicolumn{2}{|c|}{ Brazil } & \multicolumn{2}{|c|}{ Poland } & \multicolumn{2}{|c|}{ Czech Republic } & \multicolumn{2}{|c|}{ Hungary } \\
\hline & $\mathrm{BM}$ & $\%$ Growth & $\mathrm{BM}$ & $\%$ Growth & $\mathrm{BM}$ & $\%$ Growth & $\mathrm{BM}$ & $\%$ Growth \\
\hline 1996 & 361 & - & 318 & - & 247 & - & 187 & - \\
\hline 1997 & 410 & 13.57 & 470 & 47.80 & 241 & -2.43 & 249 & 33.16 \\
\hline 1998 & 571 & 39.27 & 501 & 6.60 & 264 & 9.54 & 296 & 18.88 \\
\hline 1999 & 653 & 14.36 & 593 & 18.36 & 303 & 14.77 & 313 & 5.74 \\
\hline 2000 & 763 & 16.85 & 612 & 3.20 & 353 & 16.50 & 330 & 5.43 \\
\hline 2001 & 721 & -5.50 & 766 & 25.16 & 404 & 14.45 & 305 & -7.58 \\
\hline 2002 & 948 & 31.48 & 851 & 11.10 & 451 & 11.63 & 357 & 17.05 \\
\hline 2003 & 1,203 & 26.90 & 1,055 & 23.97 & 565 & 25.28 & 466 & 30.53 \\
\hline 2004 & 1,349 & 12.14 & 1,115 & 5.69 & 630 & 11.50 & 491 & 5.36 \\
\hline 2005 & 1,397 & 3.56 & 1,238 & 11.03 & 623 & -1.11 & 530 & 7.94 \\
\hline 2006 & 1,749 & 25.20 & 1,316 & 6.30 & 720 & 15.57 & 554 & 4.53 \\
\hline 2007 & 1,928 & 10.23 & 1,182 & -10.18 & 764 & 6.11 & 563 & 1.62 \\
\hline Total & 12,053 & & 10,017 & & 5,565 & & 4,641 & \\
\hline \multicolumn{2}{|c|}{ \% Growth 1996-2007 } & $434 \%$ & & $272 \%$ & & $209 \%$ & & $201 \%$ \\
\hline
\end{tabular}

quencing greatest efforts, including the human genome. This may be considered as a very important event towards this trend, once sequencings raised questions that opened a new world for the molecular biology: new genes, their functions, expressions (transcriptomic and proteomic techniques), cloning, and structure-function correlation in proteins, among others.
Sequencing projects in Brazil required a new scientific and organizational arrangement for their performance due to their characteristics (Harvey and McMeekin 2005). The large existing networks joined hundreds of researchers together and created a new version of science operation on a regional and national scale in Brazil. 
TABLE IX

Growth of scientific production in the state of São Paulo on SCOPUS database (1996-2007).

\begin{tabular}{c|c|c}
\hline \multirow{2}{*}{ Year } & São Paulo & \multirow{2}{*}{ \% Annual Growth } \\
\cline { 2 - 3 } & Total & - \\
\hline 1996 & 3,209 & 15.61 \\
\hline 1997 & 3,710 & 10.05 \\
\hline 1998 & 4,083 & 9.21 \\
\hline 1999 & 4,459 & 5.47 \\
\hline 2000 & 4,703 & 7.99 \\
\hline 2001 & 5,079 & 15.14 \\
\hline 2002 & 5,848 & 15.85 \\
\hline 2003 & 6,775 & 11.20 \\
\hline 2004 & 7,534 & 12.98 \\
\hline 2005 & 8,512 & 21.50 \\
\hline 2006 & 10,342 & 10.92 \\
\hline 2007 & 11,471 & \\
\hline Total & $\mathbf{7 5 , 7 2 5}$ & $\mathbf{2 5 7 \%}$ \\
\hline \% Growth (1996-2007) &
\end{tabular}

TABLE X

Growth of scientific production in the state of São Paulo on ISI database (1996-2007).

\begin{tabular}{c|c|c}
\hline \multirow{2}{*}{ Year } & São Paulo & \multirow{2}{*}{ \% Annual Growth } \\
\cline { 2 - 3 } & Total & - \\
\hline 1996 & 3,717 & 17.27 \\
\hline 1997 & 4,359 & 14.80 \\
\hline 1998 & 5,004 & 17.19 \\
\hline 1999 & 5,864 & 5.27 \\
\hline 2000 & 6,173 & 4.88 \\
\hline 2001 & 6,474 & 19.71 \\
\hline 2002 & 7,750 & 15.96 \\
\hline 2003 & 8,987 & 3.51 \\
\hline 2004 & 9,302 & 12.89 \\
\hline 2005 & 10,501 & 0.75 \\
\hline 2006 & 10,580 & 11.63 \\
\hline 2007 & 11,810 & $\mathbf{2 1 8 \%}$ \\
\hline Total & $\mathbf{9 0 , 5 2 1}$ & \\
\hline \multicolumn{2}{l}{$\%$ Growth $\mathbf{1 9 9 6 - 2 0 0 7}$} &
\end{tabular}

\section{PATENTS GROWTH ANALYSIS}

It would be expected that the outstanding growth of Brazilian scientific production in molecular biology from 1996 to 2007 had been followed by an expressive increase in technological innovations in this field. This possible effect was investigated through an assessment to the number of patents registration at the United States Patent and Trademark Office (USPTO).
TABLE XI

Growth of scientific production in molecular biology in the state of São Paulo on SCOPUS database (1996-2007).

\begin{tabular}{|c|c|c|}
\hline \multirow{2}{*}{ Year } & São Paulo & \multirow{2}{*}{$\%$ Annual Growth } \\
\hline & $\mathrm{BM}$ & \\
\hline 1996 & 151 & - \\
\hline 1997 & 180 & 19.21 \\
\hline 1998 & 243 & 35.00 \\
\hline 1999 & 275 & 13.17 \\
\hline 2000 & 303 & 10.18 \\
\hline 2001 & 317 & 4.62 \\
\hline 2002 & 408 & 28.71 \\
\hline 2003 & 509 & 24.75 \\
\hline 2004 & 615 & 20.83 \\
\hline 2005 & 639 & 3.90 \\
\hline 2006 & 812 & 27.07 \\
\hline 2007 & 929 & 14.41 \\
\hline Total & 5,381 & \\
\hline \multicolumn{2}{|c|}{ \% (Growth 1996-2007) } & $515 \%$ \\
\hline
\end{tabular}

TABLE XII

Growth of scientific production in molecular biology in the state of São Paulo on ISI database (1996-2007).

\begin{tabular}{c|c|c}
\hline \multirow{2}{*}{ Year } & São Paulo & \multirow{2}{*}{ \% Annual Growth } \\
\cline { 2 - 3 } & BM & - \\
\hline 1996 & 139 & 37.41 \\
\hline 1997 & 191 & 29.84 \\
\hline 1998 & 248 & 16.13 \\
\hline 1999 & 288 & 0.69 \\
\hline 2000 & 290 & 16.90 \\
\hline 2001 & 339 & 16.81 \\
\hline 2002 & 396 & 25.25 \\
\hline 2003 & 496 & 5.24 \\
\hline 2004 & 522 & 10.54 \\
\hline 2005 & 577 & 25.13 \\
\hline 2006 & 722 & 9.28 \\
\hline 2007 & 789 & $\mathbf{4 6 8} \%$ \\
\hline Total & $\mathbf{4 , 9 9 7}$ & \\
\hline \multicolumn{2}{c}{$\%$ Growth $\mathbf{1 9 9 6 - 2 0 0 7}$} &
\end{tabular}

\section{PATENTS Registration: Brazil in the Context of}

\section{LATIN-AMERICAN COUNTRIES}

Brazil appears in the second place in the Latin-American context of patents registrations, where the increase rate in the 1996-2007 period is considered (Table XIV). During this period, Chile had an increase of 1,540\%, followed by Brazil with $365 \%$ of increase, Argentina 
TABLE XIII

Growth of scientific production in molecular biology and total scientific production of countries and the state of São Paulo on SCOPUS database (1996-2007).

\begin{tabular}{l|c|c|c}
\hline \multicolumn{1}{c|}{$\begin{array}{c}\text { Geographical } \\
\text { location }\end{array}$} & $\begin{array}{c}\text { Growth (\%) } \\
\text { of production in } \\
\text { molecular biology }\end{array}$ & $\begin{array}{c}\text { Growth (\%) } \\
\text { of total } \\
\text { production }\end{array}$ & $\begin{array}{c}\text { Growth of production in } \\
\text { molecular biology / } \\
\text { Growth of total production }\end{array}$ \\
\hline China & 1.243 & 583 & 2.13 \\
\hline São Paulo State & 515 & 257 & 2.04 \\
\hline Brazil & 434 & 236 & 1.84 \\
\hline South Korea & 354 & 291 & 1.22 \\
\hline India & 324 & 115 & 2.82 \\
\hline Poland & 272 & 74 & 3.67 \\
\hline Chile & 228 & 170 & 1.34 \\
\hline Czech Republic & 209 & 93 & 2.25 \\
\hline Hungary & 201 & 55 & 2.66 \\
\hline Mexico & 180 & 103 & 2.47 \\
\hline South Africa & 175 & 71 & 1.63 \\
\hline Argentina & 160 & 75 & 1.06 \\
\hline Germany & 62 & 38 & 0.95 \\
\hline Canada & 57 & 54 & 2.19 \\
\hline United Kingdom & 40 & 42 & 0.75 \\
\hline Japan & 35 & 16 & 1.67 \\
\hline France & 27 & 36 & \\
\hline USA & & & \\
\hline
\end{tabular}

TABLE XIV

Growth of patent registration in Brazil and in Latin American countries (USPTO patent database, 1996-2007).

\begin{tabular}{|c|c|c|c|c|c|c|c|c|}
\hline \multirow{2}{*}{ Year } & \multicolumn{2}{|c|}{ Brazil } & \multicolumn{2}{|c|}{ Argentina } & \multicolumn{2}{|c|}{ Chile } & \multicolumn{2}{|c|}{ Mexico } \\
\hline & Total & $\%$ Growth & Total & $\%$ Growth & Total & $\%$ Growth & Total & $\%$ Growth \\
\hline 1996 & 93 & - & 36 & - & 5 & - & 369 & - \\
\hline 1997 & 76 & -18.28 & 36 & 0.00 & 8 & 60.00 & 360 & -2.44 \\
\hline 1998 & 114 & 50.00 & 54 & 50.00 & 22 & 175.00 & 557 & 54.72 \\
\hline 1999 & 130 & 14.04 & 61 & 12.96 & 15 & -31.82 & 541 & -2.87 \\
\hline 2000 & 134 & 3.08 & 72 & 18.03 & 16 & 6.67 & 554 & 2.40 \\
\hline 2001 & 204 & 52.24 & 96 & 33.33 & 28 & 75.00 & 735 & 32.67 \\
\hline 2002 & 301 & 47.55 & 140 & 45.83 & 41 & 46.43 & 1,023 & 39.18 \\
\hline 2003 & 476 & 58.14 & 179 & 27.86 & 51 & 24.39 & 1,329 & 29.91 \\
\hline 2004 & 508 & 6.72 & 196 & 9.50 & 74 & 45.10 & 1,368 & 2.93 \\
\hline 2005 & 408 & -19.69 & 154 & -21.43 & 61 & -17.57 & 1,196 & -12.57 \\
\hline 2006 & 553 & 35.54 & 188 & 22.08 & 70 & 14.75 & 1,553 & 29.85 \\
\hline 2007 & 432 & -21.88 & 166 & -11.70 & 82 & 17.14 & 1,243 & -19.96 \\
\hline Total & 3,429 & & 1,378 & & 473 & & 10,828 & \\
\hline \multicolumn{2}{|c|}{ \% Growth 1996-2007 } & $365 \%$ & & $361 \%$ & & $1,540 \%$ & & $237 \%$ \\
\hline
\end{tabular}

with $361 \%$ and Mexico with $237 \%$. It is important to emphasize that what is being discussed is an increase in percentage, not in absolute numbers of patents. These results may be checked in Table XIV, where the Brazilian modest numbers may be observed at the USPTO patent database in the 1996-2007 period: the Brazilian number of patents is 3,429 , whereas the Mexican one reaches 10,828 .

When the growth rate in patents registration in molecular biology is analyzed Brazil is the leader, with an extremely expressive increase percentage of 3,700\%, followed by Argentina with $900 \%$, Mexico with $444 \%$ 
TABLE XV

Growth of patent registration in molecular biology in Brazil and in Latin American countries (USPTO patent database, 1996-2007).

\begin{tabular}{c|c|c|c|c|c|c|c|c}
\hline \multirow{2}{*}{ Year } & \multicolumn{2}{|c|}{ Brazil } & \multicolumn{2}{c|}{ Argentina } & \multicolumn{2}{c|}{ Chile } & \multicolumn{2}{c}{ Mexico } \\
\cline { 2 - 9 } & $\begin{array}{c}\text { Molecular } \\
\text { Biology }\end{array}$ & $\begin{array}{c}\% \\
\text { Growth }\end{array}$ & $\begin{array}{c}\text { Molecular } \\
\text { Biology }\end{array}$ & $\begin{array}{c}\% \\
\text { Growth }\end{array}$ & $\begin{array}{c}\text { Molecular } \\
\text { Biology }\end{array}$ & $\begin{array}{c}\% \\
\text { Growth }\end{array}$ & $\begin{array}{c}\text { Molecular } \\
\text { Biology }\end{array}$ & $\begin{array}{c}\% \\
\text { Growth }\end{array}$ \\
\hline 1996 & 1 & - & 3 & - & 0 & - & 16 & - \\
\hline 1997 & 2 & 100.00 & 5 & 66.67 & 0 & - & 20 & 25.00 \\
\hline 1998 & 4 & 100.00 & 6 & 20.00 & 0 & - & 44 & 120.00 \\
\hline 1999 & 3 & -25.00 & 3 & -50.00 & 0 & - & 24 & -45.45 \\
\hline 2000 & 11 & 266.67 & 3 & 0.00 & 0 & - & 35 & 45.83 \\
\hline 2001 & 7 & -36.36 & 3 & 0.00 & 3 & - & 36 & 2.86 \\
\hline 2002 & 18 & 157.14 & 2 & -33.33 & 4 & 33.33 & 76 & 111.11 \\
\hline 2003 & 42 & 133.33 & 11 & 450.00 & 9 & 125.00 & 100 & 31.58 \\
\hline 2004 & 52 & 23.81 & 25 & 127.27 & 5 & -44.44 & 114 & 14.00 \\
\hline 2005 & 39 & -25.00 & 14 & -44.00 & 10 & 100.00 & 113 & -0.88 \\
\hline 2006 & 62 & 58.97 & 28 & 100.00 & 10 & 0.00 & 111 & -1.77 \\
\hline 2007 & 38 & -38.71 & 30 & 7.14 & 13 & 30.00 & 87 & -21.62 \\
\hline Total & $\mathbf{2 7 9}$ & & $\mathbf{1 3 3}$ & & $\mathbf{5 4}$ & & $\mathbf{7 7 6}$ & \\
\hline \% Growth $\mathbf{1 9 9 6 - 2 0 0 7}$ & $\mathbf{3 , 7 0 0 \%}$ & & $\mathbf{9 0 0} \%$ & & $\mathbf{3 3 3 \%}$ & & $\mathbf{4 4 4 \%}$ \\
\hline
\end{tabular}

and Chile with 333\% (Table XV). However, despite this increase, the number of patents (Table XV) is still of little significance, 279, less than half the Mexican amount, which is 776 .

\section{Patents Registration: Comparison Between BRAZIL AND DEVELOPED COUNTRIES}

Taking into account the period of 1996-2007 Brazil stands very weakly when compared to developed countries, as far as the number of patents is concerned. Its growth of $365 \%$, followed by the developed countries that presented a growth rate within the range of $295 \%$, is very low if the aspiration is to reverse the great difference that separates Brazil from these countries, concerning the number of patents that were recorded at USPTO (Table XVI).

Brazil's number of patents shows a more expressive growth in molecular biology when compared to developed countries (Table XVII). However, the same arguments prevail: the increase rate of patent records should have been much higher in order to diminish the great distance that separates Brazil from the developed countries.

\section{PATENT Registration: Brazil in the SEtTing of RAPIDLY EMERGING COUNTRIES}

The growth of the total of patents in China is higher than in any other country, including the developed countries.
The Chinese growth was of 5,582\%, followed by India with a growth of $3,760 \%$, South Korea with $1,237 \%$, Brazil with $365 \%$ and South Africa with $161 \%$ (Table XVIII).

When the molecular biology patent registration is compared in the same setting, Brazil appears in the third place, with a growth of $3,700 \%$, higher than South Korea and South Africa (Table XIX). China and India have presented an overwhelming growth in the number of patent records in molecular biology of 5,275\% and $4,540 \%$, respectively.

\section{PATENT Registration: Brazil AND EAst EuRopean Countries}

The growth of patent registrations in the Czech Republic in all areas is 2,829\%, the highest among East European countries (Table XX). It is followed by Hungary with 389\%, Brazil 365\% and Poland 349\%. However, Table XX also shows that the number of patent registered is low in East European countries, even lower than in Brazil.

Brazil shows a higher position than East European countries concerning the registration of patent in molecular biology, appearing as the leader with a growth of 3,700\%, followed by Hungary with 1,050\%, Poland with 533\% and the Czech Republic with 113\% (Table XXI). 

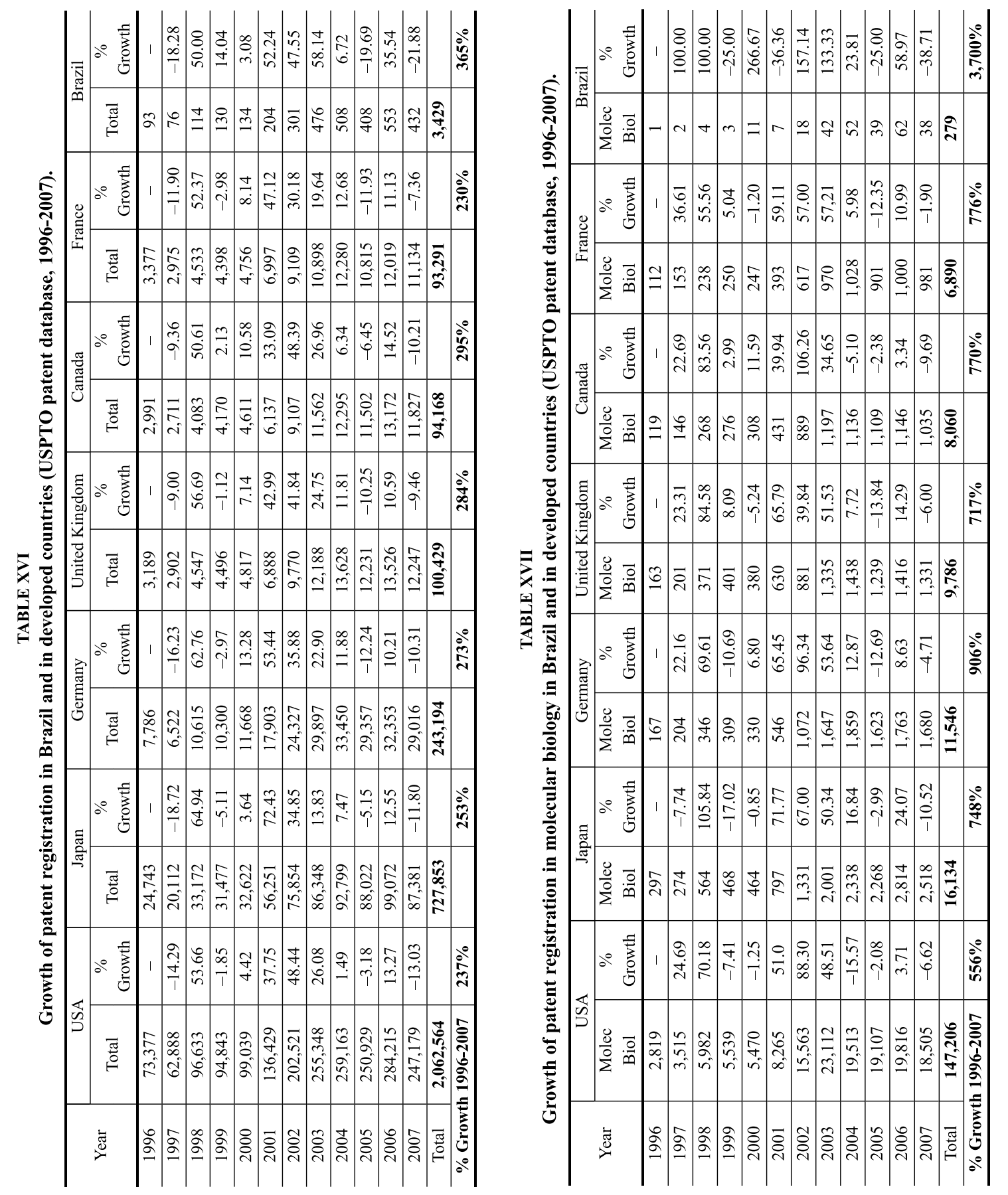
TABLE XVIII

Growth of patent registration in Brazil and in rapidly emerging countries (USPTO patent database, 1996-2007).

\begin{tabular}{c|c|c|c|c|c|c|c|c|c|c}
\hline \multirow{2}{*}{ Year } & \multicolumn{2}{|c|}{ China } & \multicolumn{2}{c|}{ India } & \multicolumn{2}{c}{ South Korea } & \multicolumn{2}{c}{ South-Africa } & \multicolumn{2}{c}{ Brazil } \\
\cline { 2 - 13 } & Total & \% Growth & Total & \% Growth & Total & \% Growth & Total & \% Growth & Total & \% Growth \\
\hline 1996 & 102 & - & 65 & - & 1,639 & - & 124 & - & 93 & - \\
\hline 1997 & 113 & 10.78 & 62 & -4.62 & 1,752 & 6.89 & 108 & -12.90 & 76 & -18.28 \\
\hline 1998 & 185 & 63.72 & 133 & 114.52 & 3,523 & 101.08 & 147 & 36.11 & 114 & 50.00 \\
\hline 1999 & 218 & 17.84 & 153 & 15.04 & 3,615 & 2.61 & 137 & -6.80 & 130 & 14.04 \\
\hline 2000 & 328 & 50.46 & 172 & 12.42 & 3,465 & -4.15 & 139 & 1.46 & 134 & 3.08 \\
\hline 2001 & 678 & 106.71 & 305 & 77.33 & 5,693 & 64.30 & 183 & 31.65 & 204 & 52.24 \\
\hline 2002 & 1,247 & 83.92 & 728 & 138.69 & 8,853 & 55.51 & 234 & 27.87 & 301 & 47.55 \\
\hline 2003 & 1,983 & 59.02 & 1,266 & 73.90 & 11,569 & 30.68 & 298 & 27.35 & 476 & 58.14 \\
\hline 2004 & 2,885 & 45.49 & 1,597 & 26.15 & 15,348 & 32.6 & 396 & 32.89 & 508 & 6.72 \\
\hline 2005 & 3,456 & 19.79 & 1,860 & 16.47 & 17,601 & 14.68 & 353 & -10.86 & 408 & -19.69 \\
\hline 2006 & 5,012 & 45.02 & 2,262 & 21.61 & 22,974 & 30.53 & 365 & 3.40 & 553 & 35.54 \\
\hline 2007 & 5,796 & 15.64 & 2,509 & 10.92 & 21,910 & -4.63 & 324 & -11.23 & 432 & -21.88 \\
\hline
\end{tabular}

TABLE XIX

Growth of patent registration in molecular biology in Brazil and rapidly emerging countries (USPTO patent database 1996-2007).

\begin{tabular}{|c|c|c|c|c|c|c|c|c|c|c|}
\hline \multirow[b]{2}{*}{ Year } & \multicolumn{2}{|c|}{ China } & \multicolumn{2}{|c|}{ India } & \multicolumn{2}{|c|}{ South Korea } & \multicolumn{2}{|c|}{ South-Africa } & \multicolumn{2}{|c|}{ Brazil } \\
\hline & $\begin{array}{c}\text { Molec } \\
\text { Biol }\end{array}$ & $\begin{array}{c}\% \\
\text { Growth }\end{array}$ & $\begin{array}{c}\text { Molec } \\
\text { Biol }\end{array}$ & $\begin{array}{c}\% \\
\text { Growth }\end{array}$ & $\begin{array}{c}\text { Molec } \\
\text { Biol }\end{array}$ & $\begin{array}{c}\% \\
\text { Growth }\end{array}$ & $\begin{array}{c}\text { Molec } \\
\text { Biol }\end{array}$ & $\begin{array}{c}\% \\
\text { Growth }\end{array}$ & $\begin{array}{c}\text { Molec } \\
\text { Biol }\end{array}$ & $\begin{array}{c}\% \\
\text { Growth }\end{array}$ \\
\hline 1996 & 4 & - & 5 & - & 17 & - & 2 & - & 1 & - \\
\hline 1997 & 7 & 75.00 & 7 & 40.00 & 24 & 41.18 & 1 & -50.00 & 2 & 100.00 \\
\hline 1998 & 12 & 71.43 & 20 & 185.71 & 32 & 33.33 & 1 & 0.00 & 4 & 100.00 \\
\hline 1999 & 16 & 33.33 & 11 & -45.00 & 39 & 21.88 & 2 & 100.00 & 3 & -25.00 \\
\hline 2000 & 10 & -37.50 & 18 & 63.64 & 40 & 2.56 & 6 & 200.00 & 11 & 266.67 \\
\hline 2001 & 30 & 200.00 & 33 & 83.33 & 80 & 100.00 & 6 & 0.00 & 7 & -36.36 \\
\hline 2002 & 57 & 90.00 & 100 & 203.03 & 132 & 65.00 & 11 & 83.33 & 18 & 157.14 \\
\hline 2003 & 108 & 89.47 & 167 & 67.00 & 271 & 105.30 & 18 & 63.64 & 42 & 133.33 \\
\hline 2004 & 170 & 57.41 & 126 & -24.55 & 319 & 17.71 & 15 & -16.67 & 52 & 23.81 \\
\hline 2005 & 155 & -8.82 & 160 & 26.98 & 365 & 14.42 & 7 & -53.33 & 39 & -25.00 \\
\hline 2006 & 212 & 36.77 & 175 & 9.38 & 463 & 26.85 & 12 & 71.43 & 62 & 58.97 \\
\hline 2007 & 215 & 1.42 & 232 & 32.57 & 439 & -5.18 & 12 & 0.00 & 38 & -38.71 \\
\hline Total & 996 & & 1,054 & & 2,221 & & 93 & & 279 & \\
\hline \multicolumn{2}{|c|}{ \% Growth 1996-2007 } & $5,275 \%$ & & $4,540 \%$ & & $2,482 \%$ & & $500 \%$ & & $3,700 \%$ \\
\hline
\end{tabular}

\section{Patent Registration: São Paulo in Comparison WITH BRAZIL}

As opposed to what happens with the scientific production measured by publications, in which São Paulo State reached approximately $37 \%$ of the national production in the 1996-2007 period, according to the Scopus database (Tables I and IX), the total number of patents registered in the same period is lower in comparison with the national rate: $34 \%$ (Table XXII). Such unfavorable performance is surprising for a state with the most dynamic industrial sector in Brazil.

Such disequilibrium is even more surprising when the molecular biology area is focused. Whereas the scientific production of São Paulo State in molecular biology on SCOPUS database reaches approximately $44.6 \%$ of the national score (Tables II and XI), the deposit of patents on USPTO reaches only $23.7 \%$ (Table XXIII). 
TABLE XX

Growth of patent registration in Brazil and in developing East European countries (USPTO patent database 1996-2007).

\begin{tabular}{c|c|c|c|c|c|c|c|c}
\hline \multirow{2}{*}{ Year } & \multicolumn{2}{|c|}{ Czech Republic } & \multicolumn{2}{c|}{ Hungary } & \multicolumn{2}{c|}{ Poland } & \multicolumn{2}{c}{ Brazil } \\
\cline { 2 - 11 } & Total & \% Growth & Total & \% Growth & Total & \% Growth & Total & \% Growth \\
\hline 1996 & 7 & - & 54 & - & 47 & - & 93 & - \\
\hline 1997 & 25 & 257.14 & 29 & -46.30 & 25 & -46.81 & 76 & -18.28 \\
\hline 1998 & 32 & 28.00 & 68 & 134.48 & 50 & 100.00 & 114 & 50 \\
\hline 1999 & 36 & 12.50 & 47 & -30.88 & 63 & 26.00 & 130 & 14.04 \\
\hline 2000 & 63 & 75.00 & 53 & 12.77 & 38 & -39.68 & 134 & 3.08 \\
\hline 2001 & 52 & -17.46 & 96 & 81.13 & 68 & 78.95 & 204 & 52.24 \\
\hline 2002 & 104 & 100.00 & 143 & 48.96 & 106 & 55.88 & 301 & 47.55 \\
\hline 2003 & 129 & 24.04 & 201 & 40.56 & 137 & 29.25 & 476 & 58.14 \\
\hline 2004 & 157 & 21.71 & 251 & 24.88 & 196 & 43.07 & 508 & 6.72 \\
\hline 2005 & 160 & 1.91 & 232 & -7.57 & 234 & 19.39 & 408 & -19.69 \\
\hline 2006 & 155 & -3.13 & 223 & -3.88 & 252 & 7.69 & 553 & 35.54 \\
\hline 2007 & 205 & 32.26 & 264 & 18.39 & 211 & -16.27 & 432 & -21.88 \\
\hline Total & $\mathbf{1 , 1 2 5}$ & & $\mathbf{1 , 6 6 1}$ & & $\mathbf{1 , 4 2 7}$ & & $\mathbf{3 , 4 2 9}$ & \\
\hline \% Growth $\mathbf{1 9 9 6 - 2 0 0 7}$ & $\mathbf{2 , 8 2 9 \%}$ & & $\mathbf{3 8 9} \%$ & & $\mathbf{3 4 9 \%}$ & & $\mathbf{3 6 5 \%}$ \\
\hline
\end{tabular}

TABLE XXI

Growth of patent registration in molecular biology in Brazil and in developing East European countries (USPTO patent database 1996-2007).

\begin{tabular}{|c|c|c|c|c|c|c|c|c|}
\hline \multirow{2}{*}{ Year } & \multicolumn{2}{|c|}{ Czech Republic } & \multicolumn{2}{|c|}{ Hungary } & \multicolumn{2}{|c|}{ Poland } & \multicolumn{2}{|c|}{ Brazil } \\
\hline & $\begin{array}{c}\text { Molec } \\
\text { Biol }\end{array}$ & $\begin{array}{c}\% \% \\
\text { Growth }\end{array}$ & $\begin{array}{c}\text { Molec } \\
\text { Biol }\end{array}$ & $\begin{array}{c}\% \\
\text { Growth }\end{array}$ & $\begin{array}{c}\text { Molec } \\
\text { Biol }\end{array}$ & $\begin{array}{c}\% \% \\
\text { Growth }\end{array}$ & $\begin{array}{c}\text { Molec } \\
\text { Biol }\end{array}$ & $\begin{array}{c}\% \% \\
\text { Growth }\end{array}$ \\
\hline 1996 & - & & 2 & - & 3 & - & 1 & - \\
\hline 1997 & 8 & - & 2 & 0 & 4 & 33.33 & 2 & 100 \\
\hline 1998 & 6 & -25.00 & 7 & 250 & 4 & 0.00 & 4 & 100 \\
\hline 1999 & 6 & 0.00 & 8 & 14.29 & 8 & 100.00 & 3 & -25 \\
\hline 2000 & 4 & -33.33 & 6 & -25.00 & 1 & -87.50 & 11 & 266.67 \\
\hline 2001 & 8 & 100.00 & 11 & 83.33 & 8 & 700.00 & 7 & -36.36 \\
\hline 2002 & 11 & 37.50 & 13 & 18.18 & 12 & 50.00 & 18 & 157.14 \\
\hline 2003 & 17 & 54.55 & 31 & 138.46 & 13 & 833 & 42 & 133.33 \\
\hline 2004 & 19 & 11.76 & 27 & -12.90 & 18 & 38.46 & 52 & 23.81 \\
\hline 2005 & 18 & -5.26 & 34 & 25.93 & 24 & 33.33 & 39 & -25 \\
\hline 2006 & 26 & 44.44 & 31 & -8.82 & 22 & -8.33 & 62 & 58.97 \\
\hline 2007 & 17 & -34.62 & 23 & -25.81 & 19 & -13.64 & 38 & -38.71 \\
\hline Total & 140 & & 195 & & 136 & & 279 & \\
\hline \multicolumn{2}{|c|}{ \% Growth 1996-2007 } & $113 \%$ & & $1,050 \%$ & & $533 \%$ & & $3,700 \%$ \\
\hline
\end{tabular}

PATENT Registration in RELATION TO SCIENTIFIC PRODUCTION

For most of the countries, the knowledge production (scientific publications) has a strong correlation with patents registration and with technological innovations (Acs et al. 2002). Despite a strong correlation between economic development and scientific and technological production has been shown (Ribeiro et al. 2006), there are strong cultural deviations concerning knowledge production and patents in different countries (Williams and McGuire 2001). The industrial sector participation in technological innovations is a feature of developed countries with relatively high per capita Gross National Product, although there may be exceptions to this rule (Guinet 2009). Table XXIV shows the correlation between patents and scientific production in the countries surveyed in this study, as well as in the state of São Paulo. It may be observed that under the ratio of 9 patent registrations per scientific publication there are 8 coun- 
TABLE XXII

Growth of patent registration in São Paulo State in comparison with Brazil (USPTO patent database 1996-2007).

\begin{tabular}{c|c|c|c|c}
\hline \multirow{2}{*}{ Year } & \multicolumn{2}{|c|}{ São Paulo State } & \multicolumn{2}{c}{ Brazil } \\
\cline { 2 - 5 } & Total & \% Growth & Total & \% Growth \\
\hline 1996 & 35 & - & 93 & - \\
\hline 1997 & 32 & -8.57 & 76 & -18.28 \\
\hline 1998 & 39 & 21.88 & 114 & 50.00 \\
\hline 1999 & 40 & 2.56 & 130 & 14.04 \\
\hline 2000 & 42 & 5.00 & 134 & 3.08 \\
\hline 2001 & 59 & 40.48 & 204 & 52.24 \\
\hline 2002 & 83 & 40.68 & 301 & 47.55 \\
\hline 2003 & 175 & 110.84 & 476 & 58.14 \\
\hline 2004 & 164 & -6.29 & 508 & 6.72 \\
\hline 2005 & 130 & -20.73 & 408 & -19.69 \\
\hline 2006 & 196 & 50.77 & 553 & 35.54 \\
\hline 2007 & 166 & -15.31 & 432 & -21.88 \\
\hline Total & $\mathbf{1 1 6 1}$ & & $\mathbf{3 , 4 2 9}$ & \\
\hline \% Growth 1996-2007 & $\mathbf{3 7 4 \%}$ & & $\mathbf{3 6 5 \%}$ \\
\hline
\end{tabular}

TABLE XXIII

Growth of patent registration in molecular biology in São Paulo State in comparison with Brazil (USPTO patent database 1996-2007).

\begin{tabular}{c|c|c|c|c}
\hline \multirow{2}{*}{ Year } & \multicolumn{2}{|c|}{ São Paulo State } & \multicolumn{2}{c}{ Brazil } \\
\cline { 2 - 5 } & BM & \% Growth & BM & \% Growth \\
\hline 1996 & 0 & - & 1 & - \\
\hline 1997 & 1 & - & 2 & 100.00 \\
\hline 1998 & 0 & - & 4 & 100.00 \\
\hline 1999 & 0 & - & 3 & -25.00 \\
\hline 2000 & 2 & - & 11 & 266.67 \\
\hline 2001 & 1 & -50.00 & 7 & -36.36 \\
\hline 2002 & 4 & 300.00 & 18 & 157.14 \\
\hline 2003 & 8 & 100.00 & 42 & 133.33 \\
\hline 2004 & 9 & 12.50 & 52 & 23.81 \\
\hline 2005 & 11 & 22.22 & 39 & -25.00 \\
\hline 2006 & 21 & 90.91 & 62 & 58.97 \\
\hline 2007 & 9 & -56.14 & 38 & -38.71 \\
\hline Total & $\mathbf{6 6}$ & & $\mathbf{2 7 9}$ & \\
\hline \% Growth 1996-2007 & $\mathbf{3 5 0 \%}$ & & $\mathbf{3 , 7 0 0 \%}$ \\
\hline
\end{tabular}

tries and São Paulo State. Among these countries are: China, three Latin American countries including Brazil, three East European countries and South Africa. China may be considered an exception because, despite presenting a strong technological innovation profile, it had not been followed by a proportional growth in the number of patents. In fact, China adopted a bi-directionally alienated position for procedures of patents deposits, either by ignoring the respect for technologies that registered patents in foreign countries or by disdaining registrations of its own innovations. However, there have been great changes in China lately, with an explosion of patents registrations (Hu and Jefferson 2008) due to large external investments in the Chinese economy and consequent changes in intellectual property legislations. The period covered by the current research considers only part of such happenings in China, whose results should strongly influence this country position in the following years.

Mexico achieved a position closer to developed countries in the patents/scientific production correlation. The fact of being geographically close to the United States and also the presence of American industries producing innovations in Mexico certainly have weighted significantly in this context.

Positions are not meaningfully changed in the molecular biology area as shown in Table XXV. Japan was in the first position concerning patents registration normalized by scientific articles in overall fields of science, but it currently reaches the third position in the molecular biology area, being replaced by USA in the first position. India, which occupies the fourth position concerning all fields of sciences, falls down to the ninth position in molecular biology. Korea, with its recognized effort for technological innovation, changes from position 3 to 7 in Tables XXV. It is amazing that São Paulo State is so badly positioned in the area of molecular biology. In fact, some companies emerged in this state as a result of its own genome program with the perspective of innovation, mainly in the agricultural area. However, up to the moment, this has not been translated into a growth of patent registrations at USPTO.

\section{FINAL CONSIDERATIONS}

The imbalance between scientific production and technological innovation in Brazil has already been surveyed and discussed by other authors (see, for example, Zanotto 2002). One of the defended positions is that universities should have a more important role in innovation, occupying the room that has been relatively relegated to a second plan until now by the private sector (Galembeck 2007). The opposite position is that universities should dedicate themselves to the production of relevant scientific results, thus giving rise to the formation of high level human resources (Brito Cruz 2005). Fol- 
TABLE XXIV

Scientific production according to the SCOPUS database and patent registration on USPTO database covering all fields of science and technology (1996-2007).

\begin{tabular}{l|c|c|c}
\hline \multicolumn{1}{c|}{$\begin{array}{c}\text { Geographic } \\
\text { localization }\end{array}$} & $\begin{array}{c}\text { Scientific } \\
\text { production } \\
\text { (SCOPUS) }\end{array}$ & $\begin{array}{c}\text { Patents } \\
\text { registrations } \\
\text { USPTO }\end{array}$ & $\begin{array}{c}\text { Patents } \\
\text { registrations/ } \\
\text { Scientific } \\
\text { production (\%) }\end{array}$ \\
\hline Japan & $1,141,800$ & 727,853 & 63.75 \\
\hline USA & $3,891,251$ & $2,062,564$ & 53.00 \\
\hline South Korea & 266,797 & 117,942 & 44.21 \\
\hline India & 343,448 & 11,112 & 32.35 \\
\hline Germany & $1,029,218$ & 243,194 & 23.63 \\
\hline Canada & 566,810 & 94,168 & 16.61 \\
\hline France & 744,941 & 93,291 & 12.52 \\
\hline Mexico & 113,021 & 10,828 & 9.58 \\
\hline United Kingdom & $1,109,614$ & 100,429 & 9.05 \\
\hline South-Africa & 6,121 & 2,808 & 4.45 \\
\hline Hungary & 65,378 & 1,661 & 2.54 \\
\hline China & $1,022,399$ & 22,003 & 2.15 \\
\hline Argentina & 66,415 & 1,378 & 2.07 \\
\hline Brazil & 202.643 & 3,429 & 1,69 \\
\hline São Paulo State & 75,725 & 1,161 & 1.53 \\
\hline Chile & 33,307 & 473 & 1.42 \\
\hline Czech Republic & 83,280 & 1,125 & 1.35 \\
\hline Poland & 188,594 & 1,427 & 0.76 \\
\hline
\end{tabular}

TABLE XXV

Scientific production according to the SCOPUS database and patent registration on USPTO database covering molecular biology (1996-2007).

\begin{tabular}{l|c|c|c}
\hline $\begin{array}{c}\text { Geographic } \\
\text { localization }\end{array}$ & $\begin{array}{c}\text { Scientific } \\
\text { production } \\
\text { (SCOPUS) }\end{array}$ & $\begin{array}{c}\text { Patents } \\
\text { registrations } \\
\text { USPTO }\end{array}$ & $\begin{array}{c}\text { Patents } \\
\text { registrations/ } \\
\text { Scientific } \\
\text { production (\%) }\end{array}$ \\
\hline USA & 393,986 & 147,206 & 37.36 \\
\hline Canada & 45,077 & 8,060 & 17.88 \\
\hline Japan & 122,809 & 16,134 & 13.14 \\
\hline Germany & 90,101 & 11,546 & 12.81 \\
\hline United Kingdom & 85,802 & 9,786 & 11.41 \\
\hline Mexico & 6,393 & 776 & 11.19 \\
\hline South Korea & 20,880 & 2,221 & 10.64 \\
\hline France & 66,662 & 6,890 & 10.34 \\
\hline India & 14,442 & 1,054 & 7.30 \\
\hline Hungary & 4,641 & 195 & 4.20 \\
\hline Argentina & 4,463 & 133 & 2.98 \\
\hline Chile & 1,962 & 54 & 2.75 \\
\hline Czech Republic & 5,565 & 140 & 2.52 \\
\hline South-Africa & 3,698 & 93 & 2.51 \\
\hline Brazil & 12,053 & 279 & 2.31 \\
\hline China & 57,342 & 996 & 1.74 \\
\hline Poland & 10,017 & 136 & 1.36 \\
\hline São Paulo State & 5,381 & 66 & 1.23 \\
\hline & & & \\
\hline
\end{tabular}


lowing this point of view, it should be the private sector role to achieve advances in technological innovations. This is undoubtedly the prevailing model in developed countries.

The effort to have expression in specific areas generates positive results, as shown in the case of genomic programs. A wel-organized and well-conducted network, with realistic resources, allowed Brazil and the state of São Paulo to achieve a dramatic expansion in scientific publications, only subdued by China.

Such fact surely constitutes a necessary leap which, however, is not sufficient for a significant rise of the technological innovation process in the area of molecular biology.

\section{ACKNOWLEDGMENTS}

This work was supported by a grant of the Fundação de Amparo à Pesquisa do Estado de São Paulo (FAPESP), Brazil, number 06/56462-9. ECG holds a fellowship for post-graduation studies from Coordenação de Aperfeiçoamento de Pessoal de Nível Superior (CAPES), Brazil. No conflict of interest has been foreseen in the present article.

\section{RESUMO}

Vários programas de sequenciamento de genoma foram lançados no Brasil no final da década de noventa e início da década de 2000. As mais importantes iniciativas foram sustentadas pelo programa ONSA (http://watson.fapesp.br/onsa/ Genoma3.htm) e visavam o domínio da tecnologia genômica e o progresso da biologia molecular para o estado da arte desta disciplina. Dois principais conjuntos de dados foram coletados no período de 1996-2007 para avaliar os resultados destes programas de genômica: a produção científica (bases de dados SCOPUS e o registro de patentes (US Patent and Trademark Office), ambos relacionados com o progresso de biologia molecular ao longo deste período. Em relação ao primeiro o Brasil de um grande passo em comparação a 17 outros países desenvolvidos e em desenvolvimento, sendo apenas superado pela China. Com relação ao registro de patentes na área de biologia molecular, o desempenho do Brasil fica bem atrás entre os países focados no presente estudo, confirmando a perdurável tendência de pobres conquistas em inovação tecnológica, quando comparado com produção científica. São discutidas as possíveis soluções para superar este desequilíbrio.
Palavras-chave: avaliação de ciência, genômica, cienciometria, biologia molecular.

\section{REFERENCES}

Acs CJ, Anselin L And VArga A. 2002. Patents and innovation counts as measures of regional production of new knowledge. Research Policy 31: 1069-1085.

Brazilian Genome Project CONSORTIUm +110 AUTHORS. 2003. The complete genome sequence of Chromobacterium violaceum reveals remarkable and exploitable bacterial adaptability. Proceedings of the Nationall Academy of Sciences 100: 11660-11665.

Brito CRUz CH. 2005. Reforma de estratégia. Folha de São Paulo, pág. 3, 22 de fevereiro.

Galembeck F. 2007. Jornal de Ciência, 10 de julho de 2007. http://www.jornaldaciencia.org.br/Detalhe.jsp?id=48604.

GUINET J. 2009. http://www.agencia.fapesp.br/materia/ 10936/busca-global.htm.

HARVEY M AND MCMEEKIN A. 2005. Brazilian genomics and bioinformatics: instituting new innovation pathways in a global context. Economy and Society 34: 634-658.

Hu AG AND JefFERSON GH. 2008. A great wall of patents: What is behind China's recent patent explosion? J Dev Econ 90: 57-68.

JUDSON HF. 1979. The eighth day of creation; makers of the revolution in biology. Simon and Schuster, New York.

Perez JF. 2002. Pesquisa: a construção de novos paradigmas. São Paulo Perspectiva 16: 30-35.

Ribeiro LC, Ruiz RM, Albuquerque EM ANd BerNARDES AT. 2006. Science in the Developing World: Running Twice as Fast? Computing in Science and Engineering 8: 81-87.

Silva ACR, Ferro JA, ReINACH FC + 62 AUthors. 2002. Comparison of the genomes of two Xanthomonas pathogens with different host specificities. Nature 417: 459-463.

Simpson AJG, REINACH FC, ARRUdA P + 113 AUthors. 2000. The genome sequence of the plant pathogen $X y l$ lela fastidiosa. Nature 406: 151-156.

Williams LK AND MCGUIRE SJJ. 2001. http://www.isnie.org/ISNIE05/Papers05/ Williams_McGuire.PDF.

ZANOtTo ED. 2002. Scientific and technological development in Brazil. The widening gap. Scientometrics 55: 411-419.

Zhangliang C AND Li-JiA Q. 1997. Plant molecular biology in China. Plant Molecular Biology Reporter 15: 273-277. 